\title{
Antelope Predation by Nigerian Forest Baboons: Ecological and Behavioural Correlates
}

\author{
Volker Sommer ${ }^{a, d}$ Adriana Lowe ${ }^{a, c}$ Gonçalo Jesus ${ }^{a, d}$ \\ Nienke Alberts ${ }^{a, b}$ Yaëlle Bouquet ${ }^{e}$ David M. Inglis ${ }^{b}$ \\ Megan Petersdorf ${ }^{f}$ Eelco van Riel ${ }^{\mathrm{e}} \quad$ James Thompson ${ }^{\mathrm{a}}$ \\ Caroline Ross ${ }^{b, d}$

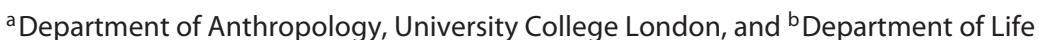 \\ Sciences, University of Roehampton, London, and 'School of Anthropology and \\ Conservation, University of Kent, Canterbury, UK; ${ }^{d}$ Gashaka Biodiversity Project, Serti, \\ Nigeria; ${ }^{\mathrm{e}}$ Institute of Biology, Université de Neuchâtel, Neuchâtel, Switzerland; \\ ${ }^{f}$ Department of Anthropology, New York University, New York, N.Y., USA
}

\author{
Key Words \\ Predation · Baboon · Bushbuck · Duiker · Forest · Nigeria
}

\begin{abstract}
Baboons are well studied in savannah but less so in more closed habitats. We investigated predation on mammals by olive baboons (Papio anubis) at a geographical and climatic outlier, Gashaka Gumti National Park (Nigeria), the wettest and most forested site so far studied. Despite abundant wildlife, meat eating was rare and selective. Over 16 years, baboons killed 7 bushbuck (Tragelaphus scriptus) and 3 red-flanked duiker (Cephalophus rufilatus), mostly still-lying 'parked' infants. Taking observation time into account, this is 1 predation per group every 3.3 months - far lower than at other sites. Some features of meat eating resemble those elsewhere; predation is opportunistic, adult males monopolize most prey, a targeted killing bite is lacking and begging or active sharing is absent. Carcass owners employ evasive tactics, as meat is often competed over, but satiated owners may tolerate others taking meat. Other features are unusual; this is only the second study site with predation records for bushbuck and the only one for red-flanked duiker. The atypical prey and rarity of eating mammals probably reflects the difficulty of acquiring prey animals when vegetation cover is dense. Our data support the general prediction of the socioecological model that environments shape behavioural patterns, while acknowledging their intraspecific or intrageneric plasticity.
\end{abstract}

\begin{tabular}{ll}
\hline KARGER & ○ 2016 S. Karger AG, Basel \\
E-Mail karger@karger.com & $015-5713 / 16 / 0872-0067 \$ 39.50 / 0$ \\
www.karger.com/fpr &
\end{tabular}

Caroline Ross

Department of Life Sciences

University of Roehampton

Holybourne Avenue, London SW15 4JD (UK)

E-Mail c.ross@ roehampton.ac.uk 


\section{Introduction}

Socioecology, the study of how an individual's interaction with its environment shapes the society it lives in [Crook and Gartlan, 1966], is central to primatology. The socioecological model assumes that similar ecological conditions will produce similar patterns in terms of social systems. This approach generated a wealth of predictions and concomitant categorizations of species or genera [Dunbar, 1988]. However, as more field studies were conducted, variations in social systems came to light, both within species and within populations, and it became evident that primates do not always fit easily into distinct categories. This triggered successive modifications and critiques of the classic model, either through refining measurements of ecological variables or by considering how phylogeny constrains phenotypic variation [Koenig and Borries, 2009; Clutton-Brock and Janson, 2012].

Documenting the flexibility and variation of behaviour of the same species across populations and across different members of the same genus can make an important contribution towards disentangling the relative importance of phylogeny versus ecology. We add to this debate by providing data on meat eating [Fichtel, 2012] in baboons. Given the close evolutionary relationship of different baboon taxa, we predict that the environment - and not phylogeny - is the most likely cause for possible variations of predatory behaviour [Chapman and Rothman, 2009].

Baboons (genus Papio) are Old World monkeys of the family Cercopithecidae (cheek pouch monkeys) that are widely distributed across Africa and into the Arabian peninsula. Traditionally recognized and phenotypically distinct morphotypes include the hamadryas or sacred (P. hamadryas), Guinea (P. papio), chacma (P. ursinus), yellow (P. cynocephalus) and olive or Anubis baboon (P. anubis) [Zinner et al., 2011; see also Oates, 2011; Kingdon, 2015]. Except for hamadryas and Guinea baboons, they have a basic social structure of multi-male multi-female groups based on female philopatry and male migration. A comprehensive review of baboon predatory behaviour is beyond the scope of this paper, which primarily aims to broaden the available database by providing additional and detailed empirical information. Nevertheless, we selected publications that document predatory behaviour across the 5 baboon taxa to ascertain general features of habitat ecology and prey selection. This preliminary review (table 1) reveals that baboon prey species include at least 3 primates, 10 ungulates, 4 rodents, 3 hares, 1 bat, 4 species of herpetofauna and 6 species of bird. Of 329 individually identified prey animals, $83.0 \%$ were mammals, $4.6 \%$ herpetofauna and $12.5 \%$ birds. The most common prey type were ungulates $(41.0 \%$; mostly immature antelopes, but also domestic goats and sheep), followed by hares (25.5\%), birds (12.5\%) and other primates (9.1\%). In 18 studies reviewed for reports on predation, $87.0 \%$ of the habitats fell in the category 'open', including grassland (56.5\%), farmland, desert, riverbeds, beach (17.4\%) and woodland (13.0\%). Only $13.0 \%$ of prey habitat was 'closed', i.e. forests, from where reported predation events accounted for only $7.4 \%$ of the total.

This bias is not surprising, given that baboons are well studied in open habitats, particularly savannah grassland, where behaviour is relatively easy to observe. However, little is known about baboon ecology and behaviour in less open environments, such as forests, into which baboons penetrate to various extents at the edges of their distribution [Higham et al., 2009]. Here, we present the first data on mammal predation by wild olive baboons inhabiting a relatively closed environment. The study site

68

Folia Primatol 2016;87:67-90 DOI: $10.1159 / 000445830$
Sommer/Lowe/Jesus/Alberts/Bouquet/Inglis/ Petersdorf/van Riel/Thompson/Ross 

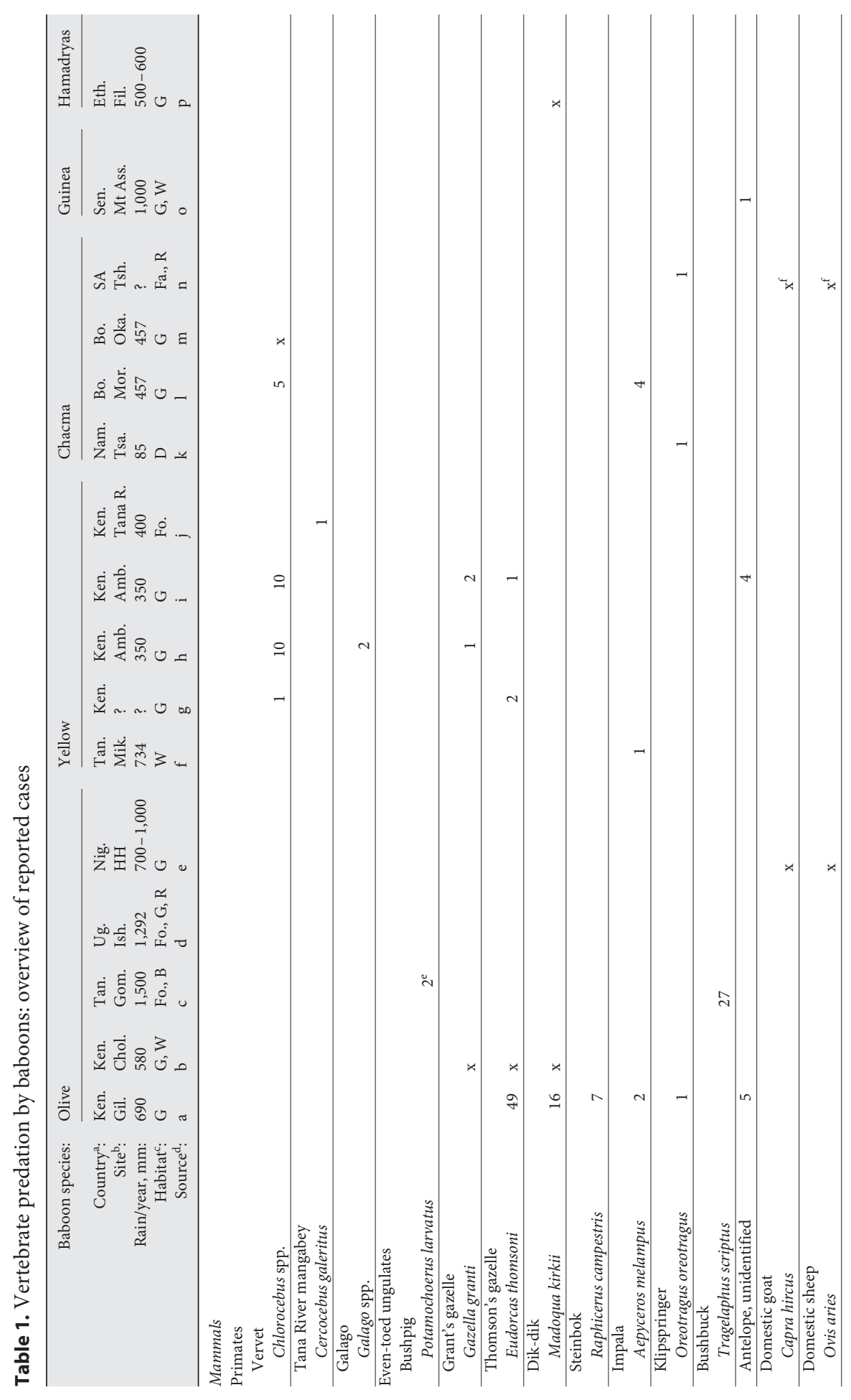


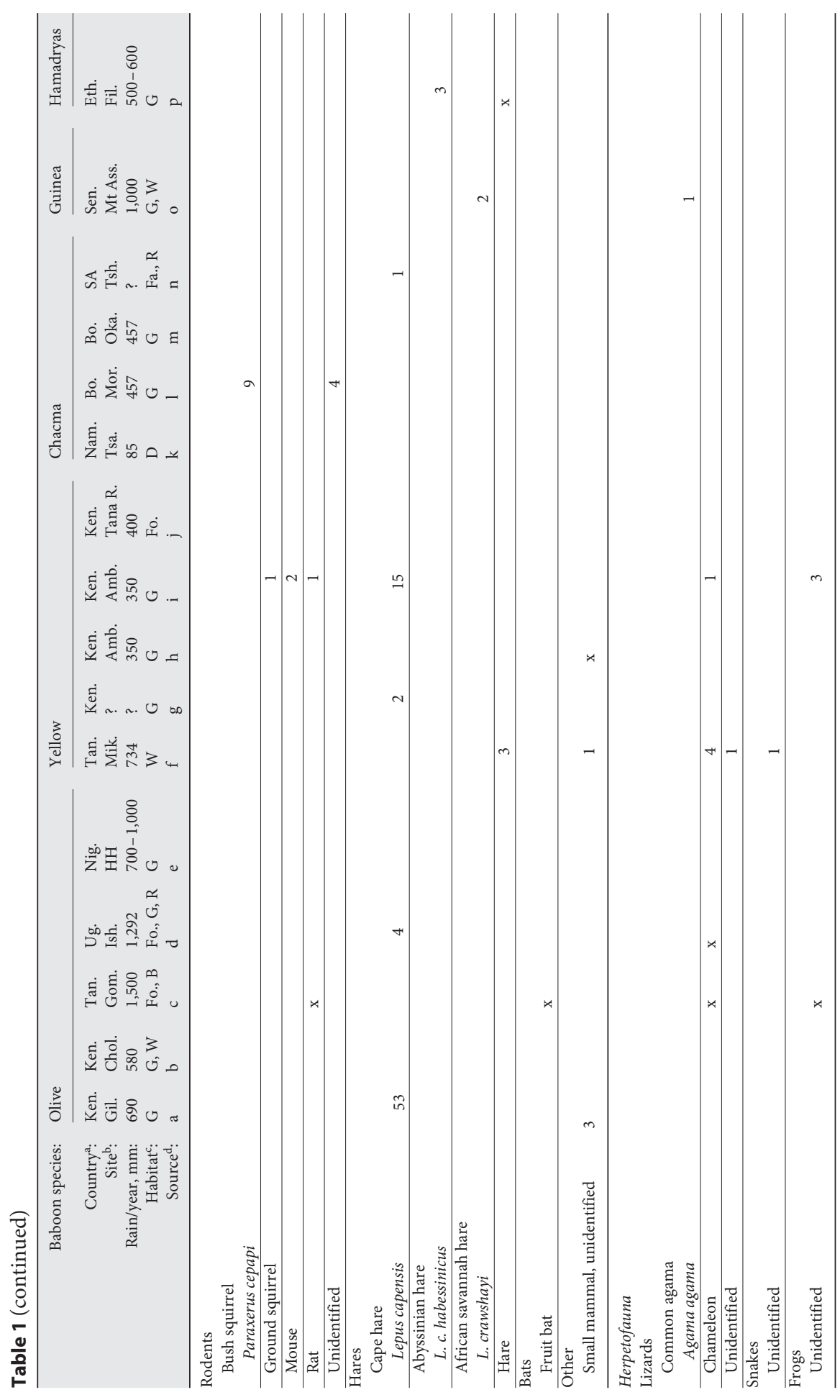

70 


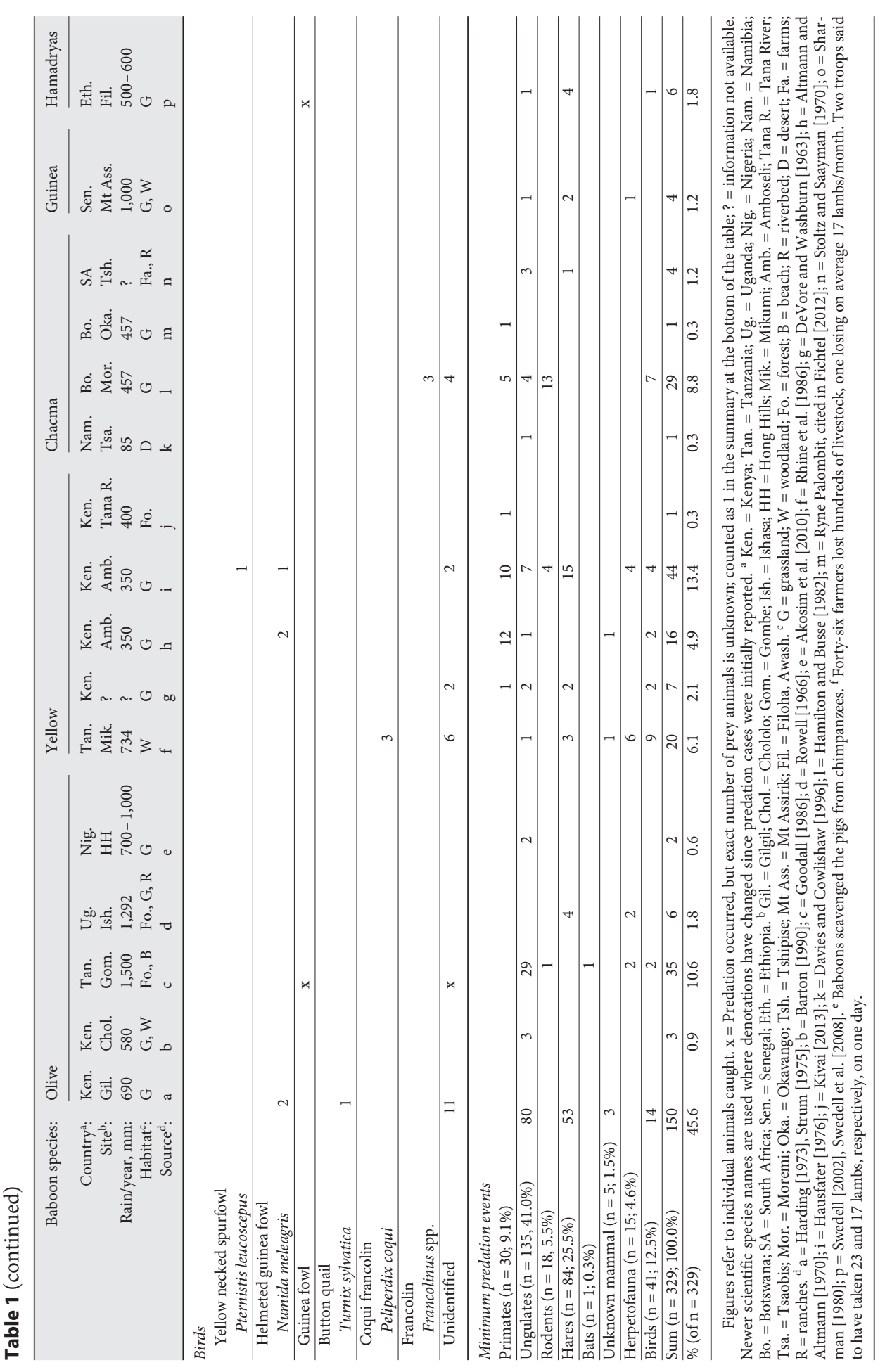


Fig. 1. Location of GGNP in North-Eastern Nigeria, West Africa.

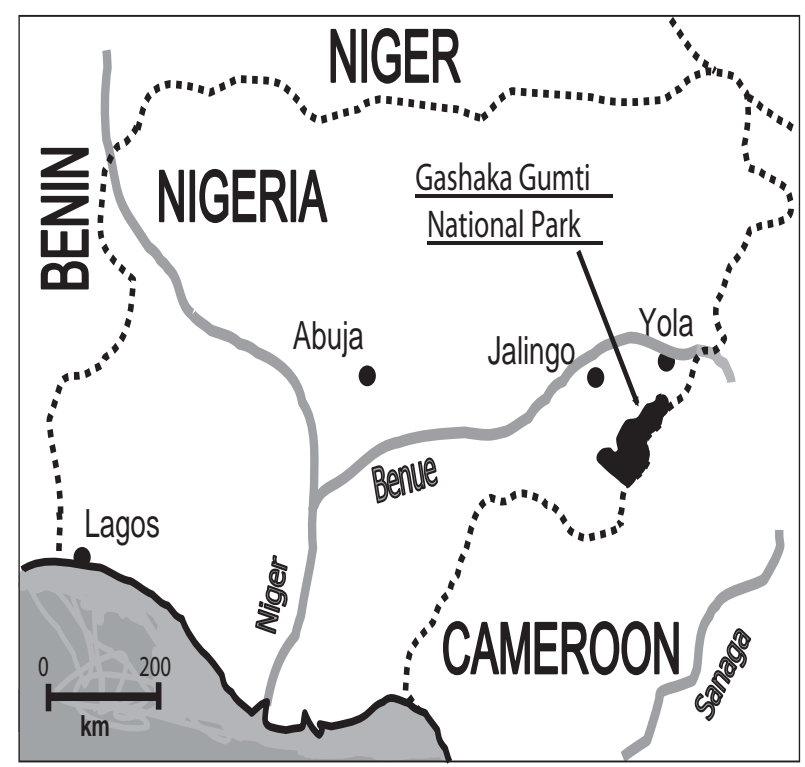

in North-Eastern Nigeria is an outlier in terms of habitat and climate. Our research is based on long-term observation of two well-habituated troops [Sommer and Ross, 2011]. For our analyses, we compare ecological features such as climate, plant cover and potential prey species across the geographical and taxonomical range of baboons against our study population living in a marginal environment at the edge of the genus' geographical distribution. As such, our data should be of interest for understanding if and how environmental factors influence variation in baboon predatory behaviour.

\section{Methods}

Study Area: Gashaka Gumti National Park/Nigeria

Our data on carnivorous behaviour of olive baboons were collected in Nigeria in the mountainous Gashaka sector of Gashaka Gumti National Park (GGNP, $6^{\circ} 55^{\prime}-8^{\circ} 13^{\prime} \mathrm{N}$ and $11^{\circ} 13^{\prime}-$ $12^{\circ} 11^{\prime} \mathrm{E}$; fig. 1). GGNP represents the northern edge of the Cameroonian Highlands and the Gulf of Guinea forests [Sommer and Ross, 2011]. The park encompasses $6,731 \mathrm{~km}^{2}$ and includes various village enclaves, mainly inhabited by settled Fulani cattle herders.

In GGNP, pronounced wet and dry seasons correspond with fluctuations in temperature and humidity [Sommer and Ross, 2011]. In the Gashaka study area, between 2000 and 2014, the mean minimum temperature was $20.9^{\circ} \mathrm{C}$, the mean maximum $32.5^{\circ} \mathrm{C}$, and the annual mean rainfall $1,945 \mathrm{~mm}$ (range 1,681-2,337 $\mathrm{mm}$ ). As for seasonality, 5 months with very little or no rainfall are followed by heavy downpours from mid-April to mid-November that constitute $97.2 \%$ of all precipitation.

The vegetation cover of the Gashaka sector of the park is a mosaic of Southern Guinea woodland-savannah, riverine and lowland rain forest, montane forest as well as grassland [Adanu et al., 2011]. The habitat of GGNP with its extensive forests is unusual for baboons and also represents the wettest of all baboon study sites to date [Higham et al., 2009]. Disease, perhaps 


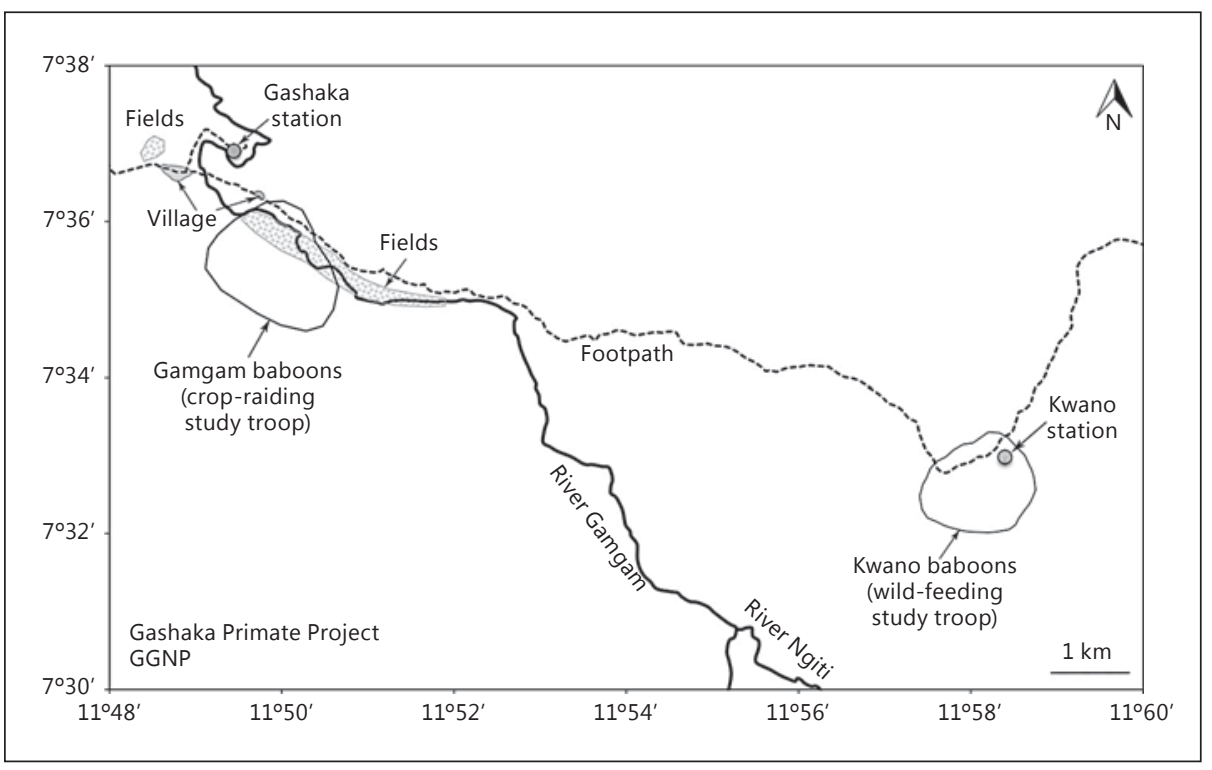

Fig. 2. Baboon study sites, indicating home ranges of the crop-raiding troop Gamgam near the village of Gashaka, and the wild-feeding troop Kwano further inside the national park. Research stations are marked by solid circles (map design: G.J.).

brought about by high rainfall [Higham et al., 2009], as well as interspecific competition might be likely reasons why baboons are often excluded from closed forests [Kingdon, 2015]. The GGNP population lives close to the southern edge of the species' western biogeographical distribution [Zinner et al., 2011]. Just a short distance to the south, baboons disappear, replaced by large forest-dwelling monkeys, in particular drills (Mandrillus leucophaeus).

\section{Study Troops: Kwano and Gamgam}

Since the year 2000, we have collected data on two baboon troops in GGNP [Higham et al., 2009; Warren et al., 2011; Ross et al., 2011], the Gamgam troop (in previous publications sometimes referred to as 'Gashaka troop' or CR, i.e. crop-raiding, troop) and the Kwano troop (previously the NR, i.e. non-raiding, troop). The troops live about $10 \mathrm{~km}$ apart, with Gamgam's range around $1 \mathrm{~km}$ outside the national park boundary, and Kwano's range inside the park (fig. 2).

Troop home ranges differ somewhat in altitude (Kwano 583 m, Gamgam 320 m), mean annual rainfall (Kwano 1,977 mm, Gamgam 1,913 mm; data for 2000-2014) and size (Kwano 1.9$2.6 \mathrm{~km}^{2}$, Gamgam 1.8-2.5 km²; data for 2009-2010 [Alberts, 2012] and 2012 [G.J., in preparation]). Troop sizes varied, depending on birth, death, immigration, and emigration. For example, between 2000 and 2008, they averaged 28.4 animals for Kwano (range 26-35) and 19.3 animals for Gamgam (range 14-23). The across-troop average was 24.3 animals, including an average of 6.2 adult females [Warren et al., 2011].

All troop members were known individually. For the purpose of this report, age-sex classes are defined as follows [Warren et al., 2011]: IM = infant male (birth to 2 years), IF = infant female (birth to 2 years), JM = juvenile male ( $>2-<6$ years), $\mathrm{JF}=$ juvenile female $(>2-<4$ years), $\mathrm{AM}=$ adult male ( $>6$ years), $\mathrm{AF}=$ adult female ( $>4$ years).

The home ranges of both troops encompass various proportions of forest and woodland. Data from an $8-\mathrm{km}$ random line transect show a greater density of forest trees (mean floor area/ 
tree $31 \mathrm{~m}^{2}$, range $6-100 \mathrm{~m}^{2}, \mathrm{SD} 20, \mathrm{n}=801$ ), compared to trees in woodland (mean floor area/ tree $48 \mathrm{~m}^{2}$, range $17-100 \mathrm{~m}^{2}, \mathrm{SD} 28, \mathrm{n}=181$ ). However, visibility is not necessarily better in woodland because, each year, much of its grass cover is deliberately burned for about 3 months (December to February). This encourages the dominance of a single grass species, the African dropseed (Sporobolus africanus), which often grows $2 \mathrm{~m}$ high and densely blankets the habitat from May to November.

The proportion of forest to woodland is $72-28 \%$ for the Kwano range versus $18-82 \%$ for Gamgam. In addition, the Gamgam troop regularly supplements its diet with maize and a variety of other crops, including subterranean items, taken from fields along the banks of the Gamgam river (which constitute about $15 \%$ of its home range).

Such differences notwithstanding, study troop baboons spend similar percentages of feeding time on principal food types ( $\mathrm{K}=\mathrm{Kwano}, \mathrm{G}=\mathrm{Gamgam}$ ): leaves (K $6 \%, \mathrm{G} 4 \%$ ), flowers (K $5 \%$, G 5\%), fruit and seeds (K 63\%, G 54\%), subterranean items (K 1\%, G 6\%), invertebrates (K 8\%, G $14 \%$ ) [Ross et al., 2011]. Members of all age-sex classes consume invertebrates such as Lepidoptera caterpillars and cocoons (57\%), aquatic fauna including crabs (20\%), Scarabaeidae beetle larvae (13\%) as well as other insects including ants and termites (9\%) [Ross et al., 2011].

Observations of both baboon troops were conducted for about 10-20 days/month, each observation period typically lasting at least $6 \mathrm{~h}$, from either 6.00 to 12.00 or 12.00 to $18.00 \mathrm{~h}$. Data collection followed a routine executed by trained field assistants who may or may not have been accompanied by students, researchers or volunteers. For example, between 2004 and 2011, observation time on troop Kwano amounted to 4,147 $\mathrm{h}$ and for troop Gamgam to 3,596 h. The combined total of $7,743 \mathrm{~h}$ translates into $968 \mathrm{~h}$ /year or $2.7 \mathrm{~h}$ /day. The comprehensive observation schedule renders it likely that we obtained representative records even about relatively rare events such as predation. Nevertheless, the detail of recorded information varied from case to case.

\section{Background Data: Potential Mammalian Prey Species}

Baboon troops that range near villages in and around Nigeria's GGNP often come into contact with domestic animals. Project field assistants Hammaunde Guruza, Maigari Ahmadu and Halidu Iliyasu, who grew up in Gashaka in farming families, report that monkeys will occasionally kill and eat chickens (Gallus gallus domesticus) as well as goats (Capra hircus) and sheep (Ovis aries) (mostly immature individuals, but also some adults; similarly reported by Akosim et al. [2010] for baboons in Nigeria's nearby Adamawa state). The typical hunting strategy involves sitting still until the potential prey is close enough so that it can be leapt at and caught, as well as chasing prey that aims to escape. Baboons in and near GGNP have also killed dogs (Canis familiaris) that confronted them, and they have bitten children and women. There are no reports about attacks on cows (Bos taurus) or horses (Equus caballus). In one instance, a troop in open grassland was seen running after and catching a scrub hare.

Thus, given that GGNP baboons can kill and eat relatively large animals, we expect the study troop monkeys to have similar abilities. Table 2 lists species of 5 orders of mammals that occur in their home ranges. Baboons elsewhere in Africa prey upon members of these orders (table 1), albeit not necessarily the same species as those found at the Nigerian site. Still, it seems reasonable to expect that study troop baboons are motivated to kill and consume individuals of some of these species.

For these study area mammals, the tabulation also lists body dimensions and the number of animals typically seen together. These factors likely influence the probability that baboons encounter and overpower such potential prey animals. While not standardized across taxa, these figures nevertheless broadly indicate the degree of sociality of potential prey species. Data on mammal group sizes were collected by varied means: (a) foot surveys of large mammals in the wider Kwano study area by field assistants and researchers totalling 14,493 h over a 4-year period (2005-2008). This translates into 3,623 h/year or $9.9 \mathrm{~h} /$ day. For these surveys, typically a single observer (and sometimes teams of 2-3 individuals) went on predetermined routes that systematically covered quadrants of a $30-\mathrm{km}^{2}$ area. Observers followed a rota of walking and pausing, while recording sightings of pigs, antelopes and primates. Surveys encompassed all hours of the daytime and all months of the year. (b) These survey data are supplemented for some taxa (giant forest hog, bushbuck, yellow-backed duiker) by records from a still-camera trap placed in front 
Table 2. Mammals inhabiting baboon study ranges at GGNP, Nigeria

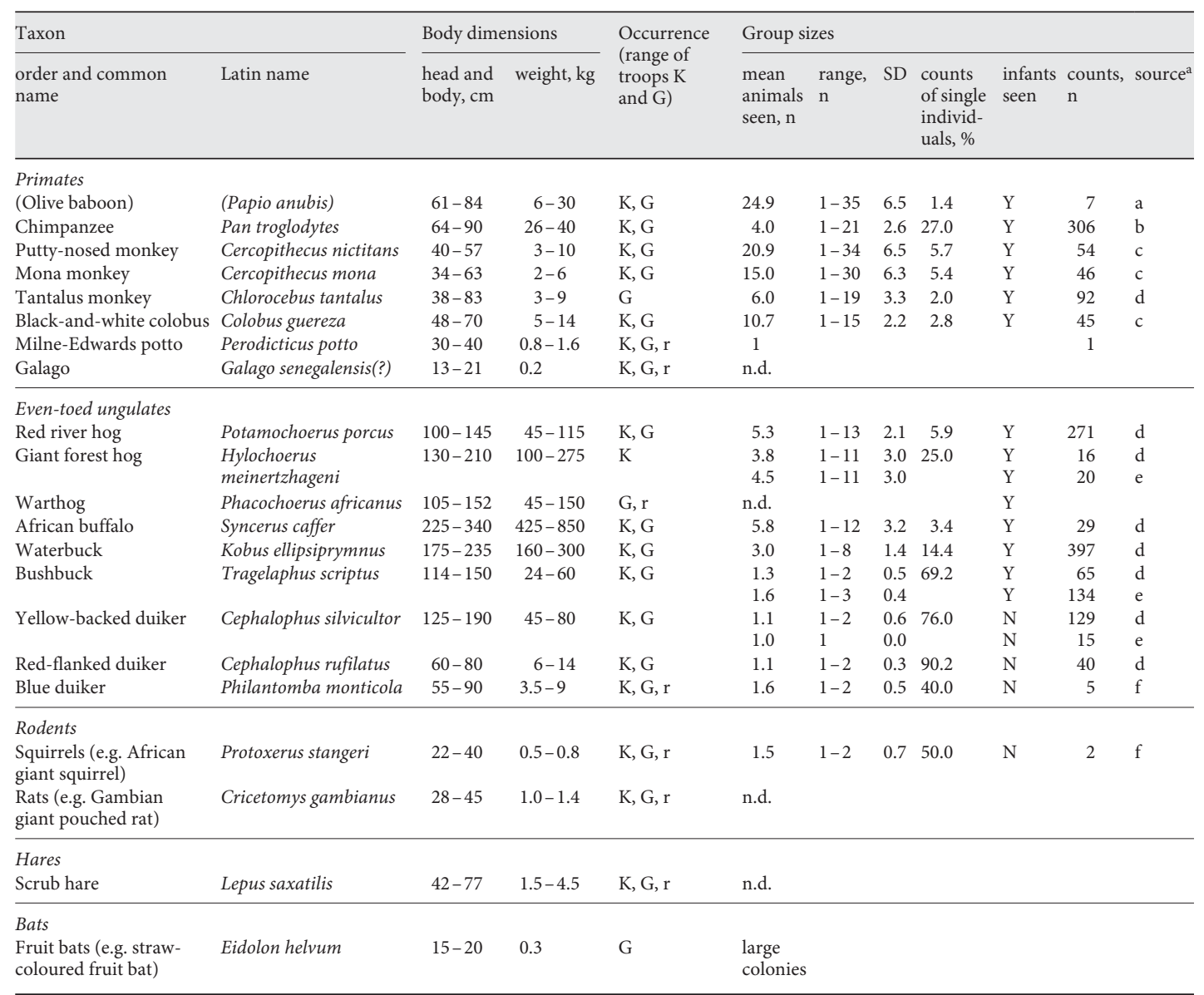

$\mathrm{K}=$ Kwano; $\mathrm{G}=$ Gamgam; $\mathrm{r}$ = rarely seen; $\mathrm{n} . \mathrm{d}$. = no data; $\mathrm{Y}=$ yes; $\mathrm{N}=$ no. Listed are representatives of orders on which baboons elsewhere prey upon. All local species are listed for the the orders Primates, Artiodactyla (even-toed ungulates) and Lagomorpha (hares), but only exemplary species for Rodentia (rodents) and Chiroptera (bats). For details of survey methods on group sizes, see text; n.d. = No data. Body dimensions from Kingdon [2015]. Data on baboons (in parentheses) are for comparison only.

a a = Higham et al. [2009]; b = Sommer et al. [2004]; c = group counts, Kwano habitat (May to December 2000); d = mammal survey, Kwano habitat (2005-2008); e = still-camera trap, mineral lick, Kwano habitat (February to April 2011, April to June 2013); f = video camera traps, Kwano habitat (2012-2014).

of a mineral lick within the Kwano baboon troop range over a 5-month period (2011, 2013). Group sizes calculated from camera trap images and foot surveys were found to be very similar. (c) Counts for some rarely seen animals (blue duiker, squirrel) are based on opportunistic records from 20 video camera traps placed across the wider Kwano habitat for 3 years (2012-2014). (d) Data for putty-nosed monkeys, mona monkeys and colobus monkeys reflect systematic group counts in the wider Kwano study area along a standardized 9.5-km route, evenly spread across the daytime, executed by Jeremiah Adanu over an 8-month period (May to December 2000). (e) Counts for chimpanzees and the study baboons themselves are based on published long-term data. 
Records during successive days might capture the same individual animals or groups. However, the counts still provide a fair indication about probabilities with which study baboons, during their daily travels, encounter certain types and numbers of animals. These can be compared against actual rates with which baboons capture and consume prey. This, in turn, will inform conclusions about opportunities and constraints that study troop baboons face with respect to predatory activities.

Apart from mammals, baboons elsewhere in Africa also eat non-mammalian vertebrates (table 1). We will therefore also report instances in which study troop baboons preyed on herpetofauna, reptiles or birds.

\section{Manuscript Preparation}

Baboon research at GGNP is directed by senior author Caroline Ross. Gonçalo Jesus collated the data for mammalian group counts and baboon observation frequencies. The report was compiled by lead author Volker Sommer who also manages the site's long-term data. All other authors observed and recorded one or more predation events.

\section{Results}

\section{Predation on Non-Mammalian Vertebrates}

Adult, subadult and juvenile study troop baboons of both sexes occasionally catch and eat small lizards such as the common agama (Agama agama). Individual monkeys of Kwano troop caught lizards on, e.g., the following days: JM Rabi, March 4, 2007, and May 1, 2007; AF Ymke, March 8, 2007; AF DrKate, April 9, 2007; AM Baki, March 1, 2007, and April 3, 2011; SM Sama, April 7, 2011. On 2 occasions, study troop baboons have been seen to kill and eat Guinea fowl, and they were seen once to consume eggs of Guinea fowl and once an unrecognized pigeon-like bird. There are no observations of baboons killing snakes, frogs or fish, despite an abundance of such animals in their home ranges.

\section{Predation on Mammals}

Baboons of troops Kwano and Gamgam regularly come into visual and close spatial contact with other mammals such as primates and ungulates (fig. 3a). However, they hardly ever display visibly heightened interest (fig. 3b). Study troop baboons have never been observed to pursue, i.e. actively 'hunt', any sympatric large mammal, although on 1 occasion, Kwano troop baboons were seen chasing after a civet (Civettictis civetta) for unknown reasons (pers. commun. by field assistant Halidu Iliyasu).

Still, over a 16-year period, study baboons are known to have obtained and eaten 10 antelopes, at least 9 of them infants. A summary of the cases described below as well as details on date, observer and troop composition are provided in table 3.

Case 1 (Red-Flanked Duiker). A field assistant hears antelope distress calls while at the riverbank. Upon walking towards the sound, he encounters an AM baboon with a dead duiker infant. The AM monopolizes the carcass and threatens other approaching baboons.

Case 2 (Bushbuck). AM Dogo is seen eating an infant bushbuck, while other baboons surround him.

Case 3 (Red-Flanked Duiker). 2 AM and AF Bera drag parts of a red-flanked duiker carcass (infant?) across the ground, i.e. a leg and hindquarter, while intermittently consuming the body parts. 
Fig. 3. Baboon prey animal species in the Kwano baboon troop home range. a AF redflanked duiker (camera trap photo: Anthony Agbor). b AF bushbuck in riverbed at mineral lick, while baboon troop passes by (camera trap photo: G.J.).

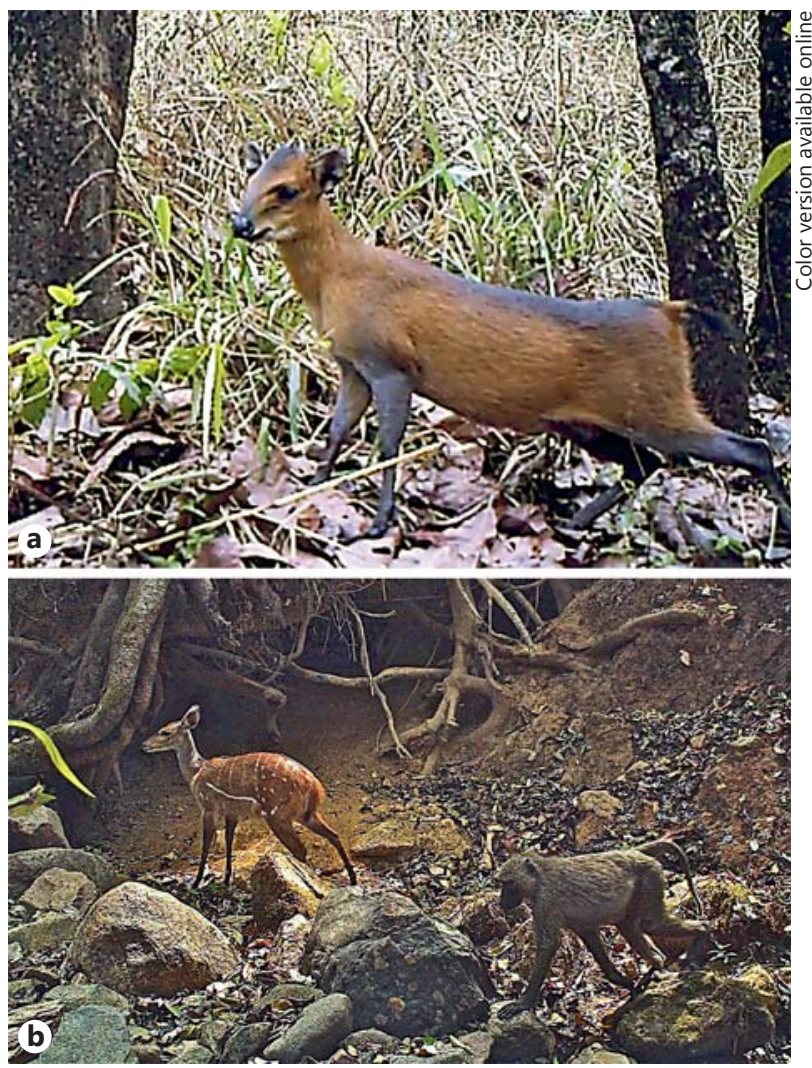

Case 4 (Bushbuck). At approximately $10.00 \mathrm{~h}$, AM Sanda catches a screaming infant bushbuck. He holds it to the ground and bites into the top of the skull, killing it. AM Sanda then sits in the undergrowth and eats the front half of the carcass. No disturbance by other baboons. AF Lami (with infant) sits within arm's reach, away, AF Sadiya and AF Ymke are within $5 \mathrm{~m}$. AF Sadiya comes close but AF Lami chases her off. AM Sanda strips off meat from the joints of one leg while holding it in both hands, with the carcass between his feet. Occasionally, smaller bones crack between his teeth. JM Jolly and JM Bonny watch from within $5 \mathrm{~m}$, while JF Tala sits on a branch just above the ground, manipulating a small piece of meat. JF Tala drops it, picks it up, rubs it between hands and along a branch, as if to clean it. She eats and continues picking at the meat as if playing. AF Sadiya, having not had access to the meat, licks blood from leaves on the ground. At $11.50 \mathrm{~h}$, AF Lami (with infant) grooms AM Sanda for about $5 \mathrm{~min}$. She then takes the bulk of the carcass and consumes meat. AM Sanda follows but does not attempt to retrieve it. He stays within $5 \mathrm{~m}$ of AF Lami while she drags the carcass around when approached by others. For the next halfhour, she intermittently strips flesh from small bones and eats. No other individuals get access to the carcass. No aggression over meat is witnessed. At 12.20 h, AF Lami sits alone, with full cheek pouches, eating bones. 
Table 3. Predation on forest antelopes by Nigerian baboons

\begin{tabular}{|c|c|c|c|c|c|c|c|c|c|c|}
\hline & 1 & 2 & 3 & 4 & 5 & 6 & 7 & 8 & 9 & 10 \\
\hline \multicolumn{11}{|l|}{ Prey type } \\
\hline $\begin{array}{l}\text { Species } \\
\text { Age }^{\mathrm{b}}\end{array}$ & $\begin{array}{l}\text { Duik. } \\
\text { Inf. }\end{array}$ & $\begin{array}{l}\text { Bush. } \\
\text { Inf. }\end{array}$ & $\begin{array}{l}\text { Duik. } \\
\text { Inf.(?) }\end{array}$ & $\begin{array}{l}\text { Bush. } \\
\text { Inf. }\end{array}$ & $\begin{array}{l}\text { Bush. } \\
\text { Inf. }\end{array}$ & $\begin{array}{l}\text { Bush. } \\
\text { Inf. }\end{array}$ & $\begin{array}{l}\text { Bush. } \\
\text { Inf. }\end{array}$ & $\begin{array}{l}\text { Duik. } \\
\text { Inf. }\end{array}$ & $\begin{array}{l}\text { Bush. } \\
\text { Inf. }\end{array}$ & $\begin{array}{l}\text { Bush. } \\
\text { Inf. }\end{array}$ \\
\hline \multicolumn{11}{|l|}{ Date } \\
\hline Month, day & $\begin{array}{l}\text { March to } \\
\text { April }\end{array}$ & $\begin{array}{l}\text { March to } \\
\text { June }\end{array}$ & April 1 & Dec. 16 & April & Nov. 9 & Feb. 16 & April & $\begin{array}{l}\text { March to } \\
\text { June }\end{array}$ & April 11 \\
\hline Time & $\sim 12.00$ & & & $\sim 10.00$ & & $\sim 11.15$ & 10.00 & $\sim 8.00$ & $\sim 11.00$ & $\sim 6.30$ \\
\hline \multicolumn{11}{|l|}{ Observer } \\
\hline Field assistants ${ }^{c}$ & $\mathrm{HG}$ & $\mathrm{HI}$ & & HI & HG & $\mathrm{MH}$ & $\mathrm{BB}, \mathrm{HI}$ & IU & IU & \\
\hline \multicolumn{11}{|l|}{ Troop } \\
\hline Name $e^{f}$ & Gam. & Kwa. & Kwa. & Kwa. & Kwa. & Gam. & Kwa. & Gam. & Kwa. & Kwa. \\
\hline Animals total & Unknown & 19 & 29 & 33 & 34 & 21 & 32 & 14 & & \\
\hline Composition & & $4 \mathrm{AM}, 10$ & $8 \mathrm{AM}, 10$ & $9 \mathrm{AM}, 10$ & $8 \mathrm{AM}, 10$ & $1 \mathrm{AM}, 5$ & $6 \mathrm{AM}, 10$ & $2 \mathrm{AM}, 3$ & $8 \mathrm{AM}$ & $5 \mathrm{AM}$ \\
\hline & & $\begin{array}{l}\mathrm{AF}, 2 \mathrm{JF}, \\
3 \mathrm{IM}\end{array}$ & $\begin{array}{l}\mathrm{AF}, 4 \mathrm{JM} \\
4 \mathrm{JF}, 1 \mathrm{IM}, \\
2 \mathrm{IF}\end{array}$ & $\begin{array}{l}\mathrm{AF}, 4 \mathrm{JM} \text {, } \\
5 \mathrm{JF}, 2 \mathrm{IM} \text {, } \\
3 \mathrm{IF}\end{array}$ & $\begin{array}{l}\mathrm{AF}, 5 \mathrm{JM} \text {, } \\
6 \mathrm{JF}, 2 \mathrm{IM} \text {, } \\
3 \mathrm{IF}\end{array}$ & $\begin{array}{l}\mathrm{AF}, 2 \mathrm{SM} \\
1 \mathrm{SF}, 7 \mathrm{JM} \\
1 \mathrm{JF}, 2 \mathrm{IM} \\
2 \mathrm{IF}\end{array}$ & $\begin{array}{l}\text { AF, } 6 \text { JM, } \\
8 \text { JF, } 2 \text { IM }\end{array}$ & $\begin{array}{l}\mathrm{AF}, 4 \mathrm{JF}, 4 \\
\mathrm{JM}, 1 \mathrm{IM}\end{array}$ & $\begin{array}{l}14 \mathrm{AF}, 4 \\
\mathrm{JM}, 1 \mathrm{JF}, \\
2 \mathrm{IM}\end{array}$ & $\begin{array}{l}13 \mathrm{AF}, 7 \mathrm{JM} \text {, } \\
1 \mathrm{JF}, 2 \mathrm{IM}, \\
4 \mathrm{IF}\end{array}$ \\
\hline \multicolumn{11}{|l|}{ Prey acquisition } \\
\hline Forest or woodland?? & $\mathrm{F}$ & $\mathrm{F}$ & & $\mathrm{F}$ & $\mathrm{F}$ & $\mathrm{W}$ & $\mathrm{F}$ & $\mathrm{W}$ & $\mathrm{F}$ & W \\
\hline After a chase? & & & & & & & & No & & No \\
\hline $\begin{array}{l}\text { While cryptic on } \\
\text { ground? }\end{array}$ & & & & & & & & Yes & & Yes \\
\hline $\begin{array}{l}\text { Attempt to immobilize } \\
\text { prey? }\end{array}$ & & & & No & & No & & $\begin{array}{l}\text { Bite back, } \\
\text { legs }\end{array}$ & No & \\
\hline First owner kills prey? & & & & Yes & & Yes & & Yes & Yes & Yes \\
\hline $\begin{array}{l}\text { Killing by biting top of } \\
\text { skull? }\end{array}$ & & & & Yes & & Yes & & Yes & Yes & \\
\hline First owner eats meat? & Yes & & & Yes & & Yes & & Yes & Yes & Yes \\
\hline $\begin{array}{l}\text { Body parts seen } \\
\text { to be eaten }\end{array}$ & & & & Head & & $\begin{array}{l}\text { Head, } \\
\text { organs }\end{array}$ & & Head & Head & Head \\
\hline Eat on ground or tree ${ }^{h}$ & G & G & & G & G & $\mathrm{G}, \mathrm{T}$ & G & $\mathrm{G}, \mathrm{T}$ & G & $\mathrm{G}, \mathrm{T}$ \\
\hline \multicolumn{11}{|l|}{ Meat passed } \\
\hline $\begin{array}{l}\text { First owner evades } \\
\text { others? }\end{array}$ & Yes & & & No & & Yes & Yes & Yes & & Yes \\
\hline $\begin{array}{l}\text { Other identified } \\
\text { individuals eating }\end{array}$ & & & $\begin{array}{l}2 \mathrm{AM} \\
1 \mathrm{AF}\end{array}$ & $\mathrm{AF}, \mathrm{JF}$ & & $\begin{array}{l}1 \mathrm{AM}, 1 \\
\mathrm{AF}, 1 \mathrm{JM}\end{array}$ & $2 \mathrm{AF}, 1 \mathrm{JM}$ & $2 \mathrm{AF}$ & $\begin{array}{l}1 \mathrm{AF}, 2 \\
\mathrm{AM}\end{array}$ & $\begin{array}{l}1 \mathrm{AM}, 2 \mathrm{AF}, \\
2 \mathrm{JM}\end{array}$ \\
\hline $\begin{array}{l}\text { Body parts seen to be } \\
\text { eaten }\end{array}$ & & & Leg, hind & Most & & Scraps & & Scraps & & Scraps \\
\hline Eat on ground or tree $\mathrm{e}^{\mathrm{h}}$ & & & G & $\mathrm{G}, \mathrm{T}$ & & G & G & $\mathrm{G}, \mathrm{T}$ & & $\mathrm{G}, \mathrm{T}$ \\
\hline
\end{tabular}

Summary of observed cases. ${ }^{\text {a }}$ Duik. $=$ Duiker; Bush. $=$ bushbuck. ${ }^{\mathrm{b}}$ Inf. $=$ Infant. ${ }^{\mathrm{c}}$ Field assistants: $\mathrm{BB}=$ Bobbo Buba; BH = Buha Hammaselbe; HI $=$ Halidu Iliyasu; $\mathrm{HG}=$ Hammaunde Guruza; $\mathrm{IU}=$ Ibrahim Usman; $\mathrm{MA}=$ Maigari Ahmadu; $\mathrm{MH}=$ Maikanti Hassan. ${ }^{\mathrm{d}}$ Researchers and volunteers: $\mathrm{AL}=$ Adriana Lowe; $\mathrm{CH}=$ Chen Hsueh-Chen; DI = David M. Inglis; DW = Doris Wu; ER = Eelco van Riel; FW = Fionnuala Walravens; GG = Gemma Gordon; $\mathrm{JT}=$ James Thompson; MP = Megan Petersdorf; NA = Nienke Alberts; RS = Ruth Sharpe; $\mathrm{YB}=$ Yaelle Bouquet. ${ }^{\mathrm{e}} \mathrm{V}=\mathrm{Video} ; \mathrm{P}=$ photo. ${ }^{\mathrm{f}} \mathrm{Gam} .=\mathrm{Gam}-$ gam; Kwa. = Kwano. ${ }^{\mathrm{g}} \mathrm{F}=$ Forest; $\mathrm{W}=$ wooodland. ${ }^{\mathrm{h}} \mathrm{G}=\mathrm{Ground} ; \mathrm{T}=$ tree. 
Case 5 (Bushbuck). Bushbuck distress calls are heard. An AM baboon is seen with an infant bushbuck. The calf's mother remains in the vicinity, tries to approach, but other baboons chase her until she runs away.

Case 6 (Bushbuck). Around $11.15 \mathrm{~h}$, observers go towards where they hear screams of an infant bushbuck. They see AF Mamakane holding down an infant bushbuck. She bites into the top of its head, then eats for the next half hour. At 11.45 $\mathrm{h}$, AF Mamakane has dragged the carcass into a patch of gallery forest, and onto a vine over a dried-up riverbed. JM Leo (AF Mamakane's son) sits underneath, looking up and around for scraps of meat. At $11.50 \mathrm{~h}$, AF Kane and IF Diana (AF Mamakane's daughter and granddaughter) arrive to sit directly underneath the vine, occasionally touching the legs of the carcass (fig. 4a). SM Augustine, who has also arrived, stays at about $2 \mathrm{~m}$ distance. At $11.51 \mathrm{~h}$, AF Mamakane moves into the woodland with the carcass in her mouth. Over the next $2 \mathrm{~h}$, she opens up the prey's belly (fig. $4 \mathrm{~b}$ ) to consume its contents and the antelope's neck, while periodically changing location. AF Kane and IF Diana remain close, as do JM Leo and JM Augustine, who at times eat left-behind scraps. At $14.04 \mathrm{~h}$, the ribs of the bushbuck are now visible. AF Mamakane continues to feed on the largely depleted contents of the belly before abandoning the carcass. JM Leo now carries it a small distance to consume the remains of the belly and spine, while appearing vigilant and nervous. He carries the carcass off in his mouth when AM Darwin approaches, then leaves it at the base of a tree, before climbing up. At $14.23 \mathrm{~h}$, AM Darwin feeds on the remains and occasionally moves with the carcass. More juveniles approach, as do AF Kane and IF Diana, who are chased away by AM Darwin. At 14.28 h, he leaves with the depleted carcass. Observers do not follow.

Case 7 (Bushbuck). Earlier in the day, bushbuck calls are heard in an area where baboons are later found by observers. When the troop is encountered, AM Kasa is seen eating an infant bushbuck. AF Lami grooms AM Kasa, who moves off with the carcass, but leaves some meat for AF Lami. Later, AF Bera and JM Jamilu also obtain some meat. A JM carries around leftover bits of the carcass for days.

Case 8 (Red-Flanked Duiker). At $9.00 \mathrm{~h}$, baboon troop scattered in open woodland. AM Fedi runs towards a depression (approx. $0.7 \mathrm{~m}$ deep, $2 \mathrm{~m}$ long, $1 \mathrm{~m}$ wide), from where an adult duiker female flees. Baboons whao-bark and scream, while one adult pursues the fleeing antelope. Duiker infant distress calls are heard. At $9.03 \mathrm{~h}$, at the depression's edge, AM Fedi is whao-barking while restraining a screaming duiker infant. At $9.12 \mathrm{~h}$, AM Fedi grabs the duiker infant's hind legs with both hands while its head points away from the baboon's chest; AM Fedi scans the surroundings, probably watching out for approaching troop members. AM Darwin dashes by. At $9.18 \mathrm{~h}$, AM Fedi bites into the infant's back (fig. 5a), swerves his own body and that of the prey $360^{\circ}$ before biting the back again; the infant bleats continuously. At $9.29 \mathrm{~h}$, several baboons whao-bark; the adult duiker female (presumably the infant's mother) runs zigzag through the grass. At $9.32 \mathrm{~h}$, the duiker female runs briefly towards the captured infant, but changes direction when 3 baboons give chase. The female escapes into the nearby forest edge. At $9.41 \mathrm{~h}, \mathrm{AM}$ Fedi bites into the infant's left thigh, runs towards the forest edge, while the screaming infant dangles from his muzzle. At $10.00 \mathrm{~h}$, on the ground, AM Fedi crouches over the screaming duiker, bites forcefully into the infant's rump; he scans the surroundings, lip-smacks towards an adult baboon passing by; AM Fedi restrains the duiker's hindlegs with both hands, before lifting the antelope, grasping around its neck with both hands. At $10.10 \mathrm{~h}$, AM Fedi 
Fig. 4. Baboon troop Gamgam - predation on bushbuck infant (2009). a AF Mamakane consumes bushbuck carcass on a vine while her daughter and granddaughter are looking on from beneath. b AF Mamakane opens up the prey's belly (photos: N.A.).
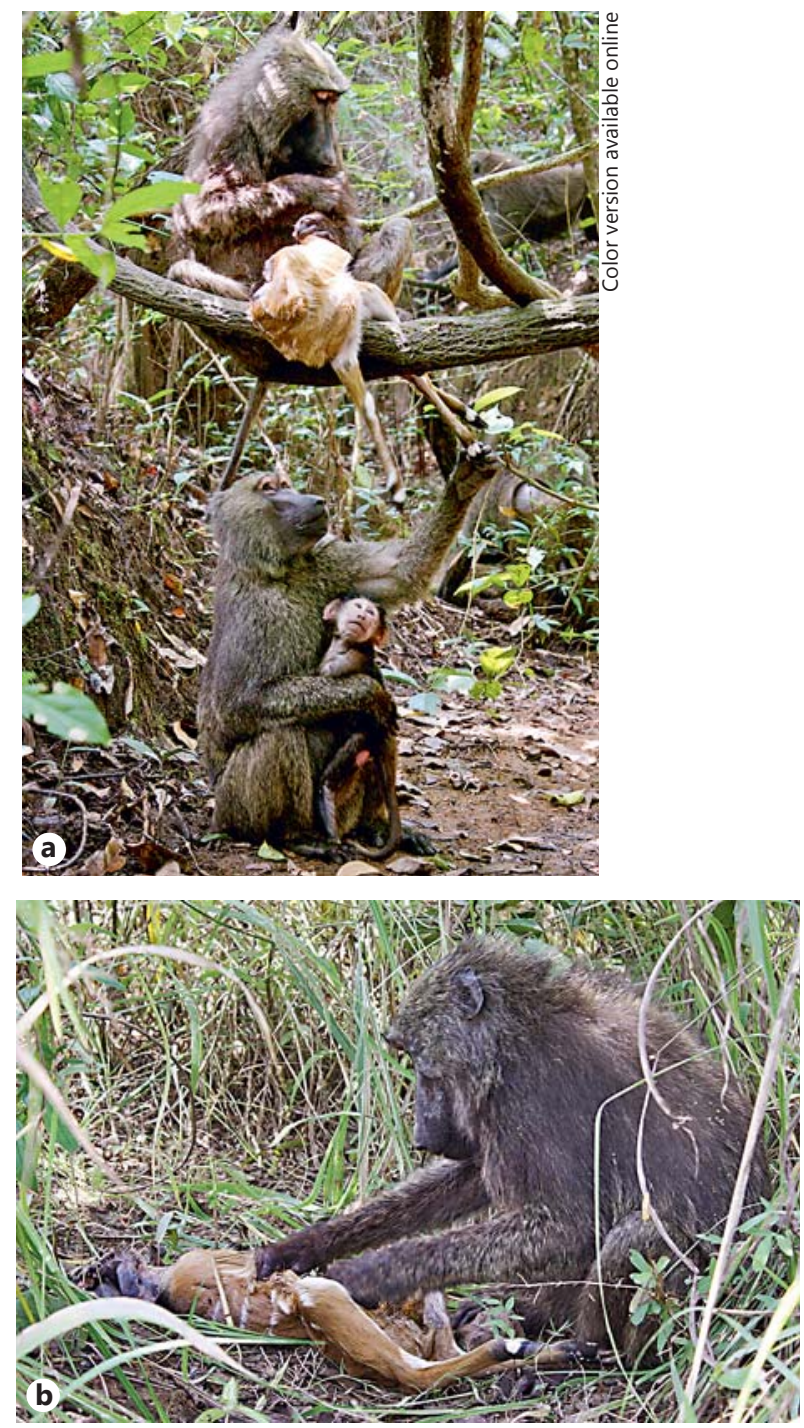

positions the infant head near the muzzle, while the duiker flings its front legs. $\mathrm{He}$ bites into the top of the infant's skull, accessing and ingesting brain matter (fig. 5b); the duiker screams terminate, the body slumps and becomes lifeless; AM Fedi chews, some white brain matter drips from his mouth. Over the next hour, AM Fedi bites another 4 times into the top of the duiker's head $(10.18,10.39,10.51,11.01 \mathrm{~h})$, while accessing and ingesting more brain matter, intermittently licking the head area and fingers of his own left hand, chewing and scanning the surroundings. At $11.28 \mathrm{~h}$, another adult baboon passes by, without trying to intervene. Soon after, other baboons approach. From $12.30 \mathrm{~h}$ onwards, AM Fedi climbs a tree, holding the prey, settles 
Fig. 5. Baboon troop Gamgam - predation on redflanked duiker infant (2012). a AM Fedi restrains prey by biting in its rump. b AM Fedi restrains prey by grasping around its neck to then kill it by biting through its skull (stills from video recorded by J.T.).
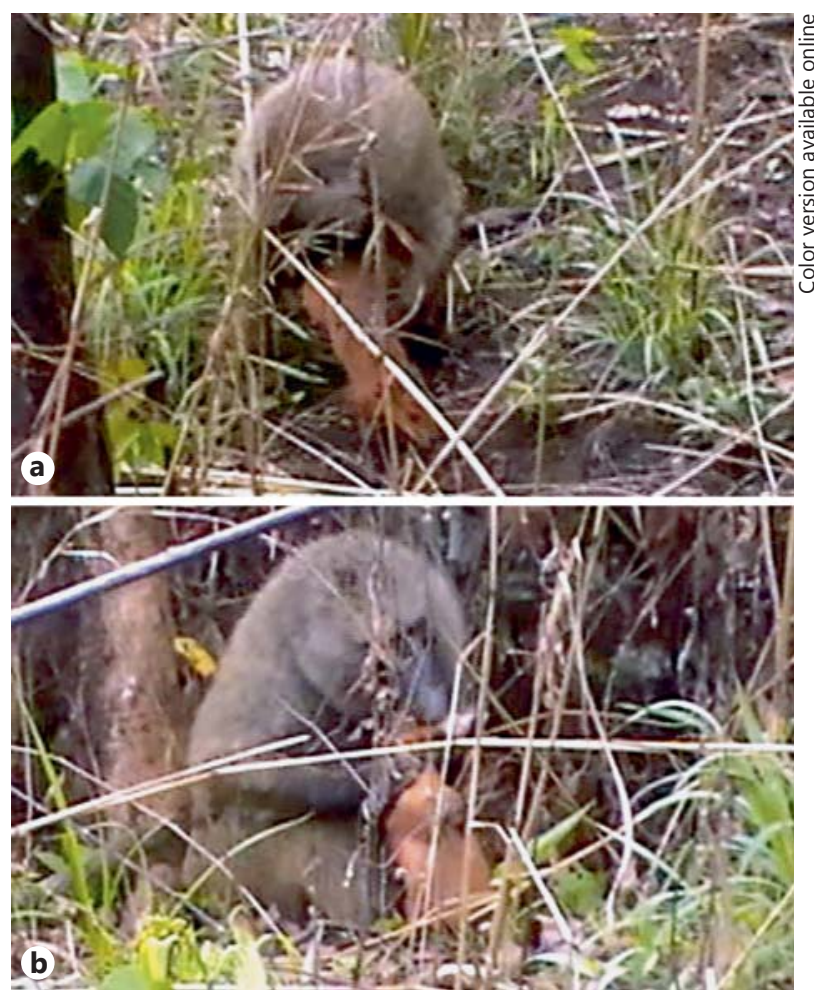

about $2 \mathrm{~m}$ above the ground, on a branch, approximately $2 \mathrm{~m}$ away from the trunk. Sitting upright, holding the carcass at its neck, with the rump dangling down, AM Fedi nibbles at the duiker's head, intermittently chewing. Other baboons climb the tree, try to approach AM Fedi, with unknown outcome. On the ground, AF Straighttail and AF Budurwa feed on scraps. Observers leave at this point.

Case 9 (Bushbuck). Observers hear screams of a bushbuck, probably including an adult. Upon arrival at the scene, AM Dali is seen on the ground, holding an infant bushbuck at the neck and biting into the top of the head. AM Dali consumes the prey for some time. Other troop members obtaining pieces of meat are AF Ladi, JM Daji, and JM Nawa. Little remains of the carcass when observers leave.

Case 10 (Bushbuck). At $6.30 \mathrm{~h}$, patch of woodland on the forest edge. Most baboons are still in their sleeping trees. Screams of an infant bushbuck are heard; several adult baboons run towards the noise. There is no sign of the mother. At $6.37 \mathrm{~h}$, AM Erni emerges with a carcass, runs up a tree where he begins to eat (fig. 6a). Another adult sits near him in the canopy but does not approach too closely. AM Erni grunts loudly, evidently a warning to others to keep their distance. AM Erni drops the carcass; other adults approach but he retrieves it and chases them off. AM Dali picks up a meat scrap, tastes it but does not eat it. At $6.39 \mathrm{~h}$, AM Erni moves off repeatedly with the carcass whenever approached by baboons or observers. At $6.52 \mathrm{~h}$, AM Erni eats in the undergrowth, first the head, then flank, then slices open the 

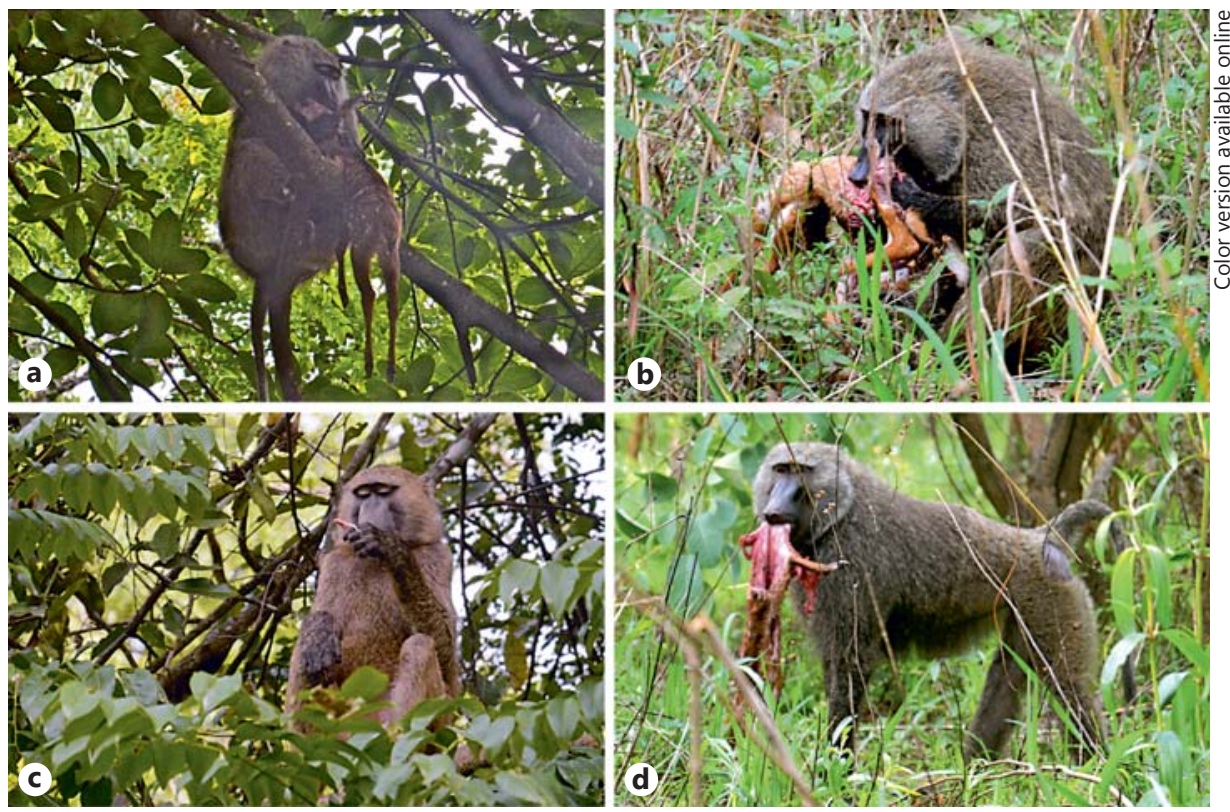

Fig. 6. Baboon troop Kwano - predation on bushbuck infant (2014). a AM Erni holds fresh kill in tree. b AM Erni bites into belly of carcass. c JM Dandi strips flesh from small bone. d AM Garrido walks through undergrowth with defleshed carcass (photos: E.v.R.).

belly (fig. 6b). AF Ymke with IF Gaetane sits within arm's reach but does not attempt to touch the meat. The infant sniffs the carcass but is ignored by AM Erni. AM Garrido and AM Dali approach aggressively. Both grunt, as does AM Erni. AM Erni runs off; AM Garrido and AM Dali chase him through the undergrowth, barking loudly. AM Garrido obtains the carcass, runs up a tree and eats the remainders. At $7.55 \mathrm{~h}$, other adults and juveniles including at least $2 \mathrm{AF}$ and $2 \mathrm{JM}$ sit below him, on branches and ground, picking up scraps (fig. 6c). The majority of the troop stay close throughout and watch this activity intently. AM Garrido repeatedly changes position in the tree and grunts whenever anyone else approaches. AM Dali circles on the ground, staring and grunting. He displaces JM sitting under AM Garrido and the meat. He gets scraps and picks at blood-stained leaves. At $8.40 \mathrm{~h}, \mathrm{AM}$ Garrido leaves the tree; at this point, the carcass is mostly skin and fur. He walks into the undergrowth (fig. 6d). A JM runs up, apparently trying to steal the meat, resulting in aggressive grunts from AM Garrido and loud screams by the JM. Others run towards the noise. The whole troop moves off into the forest. When located again by observers, the carcass is gone.

\section{Seasonal Frequency and Habitat Type of Antelope Predation}

The predation events represent a rate of 1 killing of antelope per every $1,291 \mathrm{~h}$ of observation. Given an average of 12.5 daylight hours, this translates into a rate of 1 killing every 103 full days. As for yearly quarters, kill proportions were as follows:

82

Folia Primatol 2016;87:67-90 DOI: $10.1159 / 000445830$
Sommer/Lowe/Jesus/Alberts/Bouquet/Inglis/ Petersdorf/van Riel/Thompson/Ross 
January to March (dry season) 16\%; April to June (early rainy season) 60\%; July to September (rainy season) 0\%; October to December (late rainy season) $25 \%$.

Compared to the overall proportions of habitat type, killings in closed forest are overrepresented by $30 \%$, while those in open woodland are proportionally underrepresented by $30 \%$. This contrasts with the likelihood that observers encountered (adult) prey antelopes in these habitats during the 2005-2008 foot surveys (see Methods), as sightings of bushbuck were underrepresented in forests by $24 \%$ and those of red-flanked duiker by $18 \%$.

\section{Discussion}

In the following, we compare the site-specific ecological and behavioural correlates of meat eating at GGNP (tables 2,3) with other baboon study sites (table 1), to discern if and why the predation pattern might vary. Our analyses support the assumption that environmental factors are a main influence on predatory behaviour of the two baboon study troops.

\section{Meat Eating}

With regard to non-mammalian vertebrate prey, GGNP study troop baboons occasionally killed small lizards, but hardly ever consumed birds or eggs. As for mammalian prey, despite an abundance of species, baboons killed only 7 bushbuck and 3 red-flanked duiker, probably all infants, over a 16 -year study period. Taking observation time into account, this translates into a frequency of 1 mammal killed every $1,291 \mathrm{~h}$. Despite some predation events likely going unnoticed, this is low or very low compared to other sites where a mammal is taken every $643 \mathrm{~h}$ [Stoltz and Saayman, 1970], 30 h [Rowell, 1966], 22 h [Harding, 1973] or even 12 h [Strum, 1975]. Mammalian meat is therefore not a regular source of nutrition for GGNP baboons, as it is obtained only about every 3.3 months.

Nevertheless, animal flesh clearly constitutes a desirable resource for GGNP baboons given that owners invariably resist sharing. Small lizards were easily monopolized by those who caught them. However, the much larger antelope carcasses were harder to control - not least, because possession ideally needed to be maintained for considerable time, given that catching and consuming until only scraps were left could take hours (case 9: 2 h, 10 min; case 4: 2 h, 20 min; case 6: >3 h, 12 min). Owners seemed to be wary about potential competition and regularly took evasive action (best observed in cases $1,7,8$, and 10). This did not always involve climbing a tree (as in cases 4,6 , and 10), perhaps because carcasses are more difficult to process on a branch.

Bystanders often assumed a 'vulture response' [Altmann and Altmann, 1970] by staring at the animal that ate the meat (see also Harding [1973] and Strum [1975]). As in other baboon populations, active begging gestures were never observed (see also Butynski [1982]). Still, hangers-on were able to obtain scraps of meat, in particular when an animal fed on a carcass on a branch, and parts rained down (cases 6 and 10). Baboons also licked blood from vegetation (cases 4 and 10). In total, baboons other than the first owner of the carcass obtained some meat in more than half of the cases, i.e. in at least 6 instances (cases 3, 4, 6, and 8-10). This included adults and juveniles of both sexes. 
The bulk of the carcass was passed on in at least 3 instances. In case 10, two AM ganged up on the meat owner, and one of the coalition partners was able to obtain the carcass. A JM tried the same on his own but was rebuffed by severe aggression (for correlations of meat intake with dominance rank, see Hamilton and Busse [1982]). In case 6, the carcass passed on from the original owner, an AF, to her juvenile son (for similar non-aggressive 'sharing' with offspring, see Strum [1975]). In case 4, the owner was groomed by an AF, who then made off with the carcass. Interestingly, the meatdeprived male showed little effort to retrieve the prey. Grooming a meat owner might be a female strategy, as this behaviour was observed one other time (case 7); in this instance, the female groomer did not obtain the carcass, but did get some meat the owner left behind. Baboon females in other populations have likewise been observed to steal meat from males after relaxing them through grooming [Strum, 1984; Byrne and Whiten, 1990]. Whether this is repaid somehow, perhaps via sexual favours, is unknown, but conceivable (see, e.g., Smuts [1985] for baboons; for mechanisms and functions of primate food sharing in general, see Jaeggi and Gurven [2013]).

\section{Prey Acquisition}

We have no indication of active hunting where prey is run down, let alone in the coordinated relay-chasing fashion previously observed in East African baboons [Strum, 1975]. This may explain why no adult antelopes are killed. Still, such a lack is puzzling because baboons regularly come near full-grown ungulates (fig. 3c). However, proximity might not be as close as with domestic sheep and goats, which baboons kill by lunging at when they pass by. Moreover, wild ungulates might be aware that baboons are predators and therefore maintain a critical distance.

The type of prey acquisition could be reconstructed for roughly half of the 329 prey animals listed in table 1 . Thus, regardless of baboon species, about $40 \%$ of prey animals were spotted and then chased, while $60 \%$ were grabbed after the monkeys had encountered them by chance, e.g. when they were flushed out from grass. GGNP baboons always encountered their mammalian prey opportunistically, typically while foraging. Bushbuck infants, at least in Kenya, spend time in concealment away from their mothers during the first few weeks of life [Allsopp, 1978; see also Waser, 1975]. Infant parking while mothers forage is also likely a regular occurrence at GGNP, at least for red-flanked duiker, because observers never encountered mothers with babies (table 2; neonates of blue and yellow-backed duiker were likewise never seen). Instead, $90.2 \%$ of all sightings were of single adults and the rest pairs (table 2). Moreover, duiker use freezing as a predator avoidance strategy [Croes et al., 2007; Kingdon, 2015]. Thus, whether young are 'parked' or mother and infant freeze, kills typically happen when baboons are 'quite literally tripping over their prey' [Harding, 1973, p. 588] (see also Goodall [1986], for chimpanzees stumbling over bushbuck calf). This antelopetypical pattern of infant rearing might explain why ungulates represent such a large segment of prey animals for baboons across Africa (41.0\%; table 1).

In fact, immature animals constitute the vast majority of prey animals for all baboon species. Age can be discerned for $112(34.0 \%)$ of 329 prey animals listed in table 1. Of these, $89.2 \%$ were non-adults ('fledgling', 'neonate', 'infant', 'juvenile', 'subadult'). Immature individuals constituted the following proportions of prey animals of known ages within different clades: primates, $100 \%(\mathrm{n}=18$ prey animals); ungulates, $100 \%(\mathrm{n}=75)$; hares, $67 \%(\mathrm{n}=3)$; rodents $0 \%(\mathrm{n}=11)$. 
Although adult duiker and bushbuck are seen throughout the year in the GGNP study area, predation is highly seasonal, occurring mainly during the early rainy season (April to June) with a smaller peak during the late rainy season (October to December; table 3 ). As infants constituted $90-100 \%$ of the prey animals, this is probably due to a calving peak. In East and South-Eastern Africa, free-ranging or wild bushbuck and common duiker breed throughout the year. Still, duiker have a calving peak in the dry season (March) and another one in October/November [Dasmann and Mossman, 1962; Bowman and Plowman, 2002], while bushbuck calving peaks twice, in February and September [Ables and Ables, 1971]. However, in Uganda, bushbuck calving peaks during the onset of the rainy season [Apio et al., 2009]. Such birth seasonality coincides well with our own data on predation.

During the inferred wet-season calving peak at GGNP, woodlands are blanketed by tall grass [Sommer and Ross, 2011], which provides much better cover than forests where visibility is less compromised during the rains. This could explain why killings in closed forest were overrepresented, while those in woodland were considerably underrepresented - despite the fact that the reverse was true for sightings of adult bushbuck and red-flanked duiker. Although we do not know if calves are predominantly parked in forest or woodland, this supports an earlier hypothesis [Hausfater, 1976] that declining cover leads to increased predation rates by baboons. Nevertheless, we also cannot exclude that baboons obtain their prey predominantly in forest simply because both troops travel preferentially in gallery forest [Alberts, 2012].

However, like other studies [Rhine et al., 1986], we did not find support for the hypothesis that a reduced availability of green vegetation and insects during the dry season causes increased meat eating [Hausfater, 1976] - given that dry-season predation was relatively rare at GGNP. Instead, it seems more likely that calving peaks reflect synchronization of parturition with the time when suitable food is available to the lactating mother or her soon to-be-weaned calf. Duiker are generally frugivorous, with fruit making up to $78 \%$ of the diet [Wenninger and Shipley, 2000], while bushbuck prefer to browse on shrubs and herbs [Apio et al., 2009]. Thus, it is not surprising that antelope predation at GGNP peaks with the onset of the rainy season when fresh herbs and shoots are more abundant and when fruit production of study area trees and associated vines is highest [Sommer et al., 2012].

The crypsis of parked duiker and bushbuck calves gives way to frantic bleating and screams once they are caught (cases 1, 4, 5, 7, and 9). However, mothers were unable to aid caught offspring as they were chased by other baboons when they ran towards their infants (cases 5 and 8). Nevertheless, the baboons are clearly struggling to retain caught antelopes, evidently lacking a strategy to quickly immobilize their catch. Instead, prey owners endeavour to restrain prey by pressing it to the ground or holding it by its hind legs or neck (cases 4, 6, and 9). Similarly, baboons at other sites do not appear to make any systematic attempt to kill their prey before eating it either [Harding, 1973]. Whenever an actual killing was witnessed (cases 4, 6, 8, and 9), baboons bit into the top of the infant's skull. This happened a while after the prey had been caught, perhaps because the owner first tried to find a location relatively undisturbed by troop mates. Thus, skull bites should not be interpreted as a targeted killing bite, but as an effort to obtain the most desirable body part, i.e. the brain (similar to chimpanzee meat eating; e.g. Goodall [1986]). This conflicts with reports for baboons at Gilgil/Kenya, where antelope brain was generally eaten last [Harding, 1973], while the skull was not at all accessed at Amboseli/Kenya [Hausfater, 1976]. Still, the ques- 
tion remains why an immobilizing bite is not administered before the prey is carried off to a convenient spot.

As for potential sex differences, $\mathrm{AF}$ are the main catchers and killers of mammals in bonobos [Hohmann and Fruth, 2008], while AM take up this role in chimpanzees [Stanford, 1998] and human hunter-gatherers [Power et al., 2013]. As for baboons, the catcher's age-sex class was specified for 197 (59.8\%) of the 329 prey animals listed in table 1 . Overall, AM caught $79.2 \%$ of all prey, AF $16.8 \%$ and younger animals $4.1 \%$. Noticeable differences exist with respect to prey taxa $(n=$ number of prey animals for which age-sex class of catcher is known; $\mathrm{AM} \%, \mathrm{AF} \%=$ percentage caught by Adult Males, Adult Females): primates, $\mathrm{n}=28, \mathrm{AM} 100.0 \%$, $\mathrm{AF} 0 \%$; ungulates, $\mathrm{n}=81, \mathrm{AM}$ 95.1\%, AF 4.9\%; rodents, $\mathrm{n}=3$, AM 33.3\%, AF 66.6\%; hares, $\mathrm{n}=56$, AM 67.9\%, AF $30.4 \%$; herpetofauna, $\mathrm{n}=5, \mathrm{AM}=60.0 \%$, AF $40.0 \%$; birds, $\mathrm{n}=22$, AM $40.9 \%$, AF $27.3 \%$. Thus, AF hardly ever catch larger prey such as primates and ungulates. This is true for all species of baboon.

While largely circumstantial, it seems as if AM play also a more active role in antelope predation at GGNP, given that they caught them in the 2 actually witnessed cases. When observers arrived later, an AF owned the carcass in a single case, compared to 6 cases when an AM owned it. However, we cannot exclude the possibility that males had taken fresh prey from females as these should come across cryptic prey with greater probability, given that study troops had an average of $4.3 \mathrm{AM}$ compared to 6.2 AF [Warren et al., 2011]. The actual killing was executed by AM in 4 of the 5 cases where this was witnessed and by an AF in the remaining case. Subsequently, AM consumed meat for much longer than other age-sex classes.

It seems likely that these sex differences are due to the much larger body size and fighting power of AM baboons and perhaps that they are unencumbered by infant care [Rhine et al., 1986]. Hausfater [1976] had hypothesized that baboon females acquire animal nutrients primarily through feeding on invertebrates, while males do so by preying on vertebrates. This suggestion is not supported by data for GGNP baboons, mainly because of the rarity of vertebrate predation, but also a lack of apparent sex differences with respect to invertebrate feeding [Ross et al., 2011].

Prey Species

Predatory behaviour of the Nigerian study troop baboons is evidently very specific, as only two of the many sympatric large mammal species were eaten. Various factors are likely to affect prey selection at this site.

Apart from GGNP, bushbuck consumption by baboons is only reported for Gombe/Tanzania, where it is likewise restricted to calves [Goodall, 1986] (table 1). The Gombe habitat, like GGNP, is largely a woodland-forest mosaic, albeit noticeably drier. There are no duiker at Gombe, and there is no report on baboons consuming duiker at any other sites, which are almost all savannah habitats. As these small antelopes prefer forested areas, it is no surprise that reports of them being eaten by baboons are currently restricted to GGNP.

Still, the question remains why other study area mammals are not preyed upon. At least two taxa of these sympatric mammals are eaten elsewhere by baboons - hares and vervet monkeys (table 1). However, hare species consumed at other places prefer completely open grassland, while lagomorphs at GGNP are scrub hares. These are heavier and also favour more cover such as scrubby grass within woodlands [Kingdon, 2015]. Such traits might make it more difficult for GGNP baboons to catch them.

86

Folia Primatol 2016;87:67-90 DOI: $10.1159 / 000445830$
Sommer/Lowe/Jesus/Alberts/Bouquet/Inglis/ Petersdorf/van Riel/Thompson/Ross 
The vervet-like primates at GGNP are tantalus monkeys, which albeit often terrestrial, can easily escape into the relative safety of trees, an opportunity lacking in more open habitats. The other monkeys at GGNP, i.e. colobus and guenons, might be even better protected from baboons because of their almost exclusively arboreal lifestyle.

Grouping patterns of potential prey (table 2) may also influence which species at GGNP fall victim to baboons and which do not. Piglets would seem like an obvious target, but might be hard to catch as they always travel with adults that are likely to defend them. Groups of red river hog average 5 animals, with a maximum of 13 , while those of giant forest hog average 4 animals, with a maximum of 11 (table 2). In fact, the only report of baboons eating suids comes from Gombe/Tanzania where baboons scavenged bushpig from chimpanzees [Goodall, 1986] (table 1). Infants of other antelopes may also be protected because they travel with adults. Buffalo groups at GGNP average 6 animals, with a maximum of 12, while those of waterbuck average 3 animals, with a maximum of 8 (table 2).

The group size explanation for why baboons do not prey upon certain species cannot be invoked for the remaining two antelopes - yellow-backed duiker and blue duiker. These are seen at the most in pairs, but in $76 \%$ and $40 \%$ of counts as single individuals, respectively (table 2). They are also likely to park their infants, as these were never seen by observers or on camera traps. Blue duiker seem rare in the study area, as they were very rarely seen during foot surveys (table 2). Yellow-backed duiker, on the other hand, were seen $2-3$ times more commonly ( $\mathrm{n}=129$ sightings) than bushbuck $(n=65)$ and red-flanked duiker $(n=40)$. Camera traps reveal that redflanked duiker are active only during the day, which means that their infants are parked while the baboons are awake. Yellow-backed duiker, on the other hand, are predominantly active during the night; thus, mothers will be together with their infants when the baboons stumble across them. However, bushbuck are likewise largely nocturnal. It therefore remains largely unclear why yellow-backed duiker were not preyed upon, as at least their infants fit the same general pattern as the two other antelope prey species.

\section{Conclusions}

We provide the first detailed data on predatory behaviour of baboons in a very wet study area in Nigeria with ample vegetation cover that includes forest and tall grass. Some features of meat eating by GGNP baboons resemble those at sites elsewhere. For example, predation is opportunistic, and while it is unknown whether AM actually catch most prey, they do monopolize most of it; there is no targeted killing bite, and while hangers-on are able to obtain scraps of meat, begging by bystanders or active sharing of meat is absent. Owners of a carcass typically employ evasive tactics, as meat is often aggressively competed over. Still, satiated meat owners sometimes tolerate theft, particularly in the context of male-female and mother-offspring interaction. However, some features are unusual, as this is only the second study site where baboon predation on bushbuck has been observed and the only one for duiker. This atypical prey selection seems to reflect the difficulty of acquiring prey animals outside the usual savannah habitat of baboons, i.e. when vegetation cover is dense and when potential arboreal prey can find safety in trees. GGNP baboons may therefore be restricted to opportunistic predation on still-lying, parked antelope infants. This 
could explain why, despite an abundance of other wildlife, predation on large mammals is extremely rare at GGNP. Meat makes up a larger portion of the diet at other baboon sites, although it remains unclear how important this source of nutrition is. In any case, although clearly a desired commodity, mammalian meat is not essential for the survival of baboons at GGNP. Here, the bulk of animal matter is ingested via occasional predation on lizards and the virtually daily consumption of invertebrates.

Our data do not substantiate classic conclusions of the socioecological model that may lead to rather rigid categorizations of animal societies [Dunbar, 1988]. Our findings instead acknowledge intraspecific and intrageneric plasticity within closely related taxa. With this, at least for the predatory behaviour of different baboon populations, we support the model's general prediction that the environment (and not phylogeny or stochasticity) causes behavioural variation.

\section{Acknowledgements}

Fieldwork was enabled by permits from the Nigeria National Parks Service to the Gashaka Biodiversity Project and its predecessor, the Gashaka Primate Project, which received generous core funding from the North of England Zoological Society/Chester Zoo Nigeria Biodiversity Programme. Gonçalo Jesus was supported by a scholarship from the Portuguese Fundação para Ciência e Tecnologia. Camera trapping was enabled by the Department of Primatology, Max Planck Institute for Evolutionary Anthropology, Leipzig, through volunteer Anthony Agbor. Field assistants Bobbo Buba, Halidu Iliyasu, Hammaunde Guruza, Ibrahim Usman, Maikanti Hassan, Maigari Ahmadu, Buba Hammaselbe, and Felix Vitalis were indispensable in this collection of field data.

\section{References}

Ables ED, Ables J (1971). Seasonal breeding in bushbuck (Tragelaphus scriptus Pallus, 1776). East African Wildlife Journal 9: 146-149.

Adanu J, Sommer V, Fowler A (2011). Hunters, fire, cattle: conservation challenges in eastern Nigeria, with special reference to chimpanzees. In Primates of Gashaka. Socioecology and Conservation in Nigeria's Biodiversity Hotspot (Sommer V, Ross C, eds.), pp 55-100. New York, Springer.

Akosim C, Joseph J, Egwumah PO (2010). Assessment of feeding behaviour of baboons (Papio anubis) in Hong Hills Adamawa State, Nigeria. Journal of Research in Forestry, Wildlife and Environment 2: $60-72$.

Allsopp R (1978). Social biology of bushbuck (Tragelaphus scriptus Pallus 1776) in the Nairobi National Park, Kenya. East African Wildlife Journal 16: 153-165.

Alberts N (2012). Fission-Fusion Dynamics of Olive Baboons (Papio anubis) in Gashaka-Gumti National Park. PhD thesis, University of Roehampton, London.

Altmann SA, Altmann J (1970). Baboon Ecology: African Field Research. Chicago, University of Chicago Press.

Apio A, Muwanika VB, Plath M, Wronski T (2009). Seasonal variation in reproductive behaviour of bushbuck (Tragelaphus scriptus Pallas, 1766) in an equatorial savannah ecosystem. African Journal of Ecology 47: 592-597.

Barton RA (1990). Foraging Strategies, Diet and Competition in Olive Baboons. PhD thesis, University of St Andrews.

Bowman V, Plowman A (2002). Captive duiker management at the Duiker and Mini-Antelope Breeding and Research Institute (Dambara), Bulawayo, Zimbabwe. Zoo Biology 21: 161-170.

Butynski TTM (1982). Vertebrate predation by primates: a review of hunting patterns and prey. Journal of Human Evolution 11: 421-430.

Byrne R, Whiten A (1990). Tactical deception in primates: the 1990 database. Primate Report 27: 1-101. Chapman CA, Rothman JM (2006). Within-species differences in primate social structure: evolution of plasticity and phylogenetic constraints. Primates 50: 12-22. 
Clutton-Brock T, Janson C (2012). Primate socioecology at the crossroads: past, present, and future. Evolutionary Anthropology 21: 136-150.

Croes BM, Laurance WF, Lahm SA, Tchignoumba L, Alonso A, Lee ME, Campbell P, Buij R (2007). The influence of hunting on antipredator behaviour in central African monkeys and duikers. Biotropica 39: $257-263$.

Crook JH, Gartlan JS (1966). Evolution of primate societies Nature 210: 1200-1203.

Dasmann RF, Mossman AS (1962). Reproduction in some ungulates in Southern Rhodesia. Journal of Mammalogy 43: 533-537.

Davies JG, Cowlishaw G (1996). Baboon carnivory and raptor interspecific competition in the Namib Desert. Journal of Arid Environments 34: 247-249.

DeVore I, Washburn SE (1963). Baboon ecology and human evolution. In African Ecology and Human Evolution (Howell FC, Bourliere F, eds.), pp 335-367. Chicago, Aldine.

Dunbar RIM (1988). Primate Social Systems. London, Croom Helm.

Fichtel C (2012). Predation. In The Evolution of Primate Societies (Mitani JC, Call J, Kappeler PM, Palombit AR, Silk JB, eds.), pp 169-194. Chicago, University of Chicago Press.

Goodall J (1986). The Chimpanzees of Gombe. Patterns of Behaviour. Massachusetts, Harvard University Press.

Hamilton WJ, Busse C (1982). Social dominance and predatory behaviour of chacma baboons. Journal of Human Evolution 11: 567-573.

Harding RSO (1973). Predation by a troop of olive baboons (Papio anubis). American Journal of Physical Anthropology 38: 587-592.

Hausfater G (1976). Predatory behavior of yellow baboons. Behaviour 56:44-68.

Higham JP, Warren Y, Adanu J, Umaru BN, MacLarnon AM, Sommer V, Ross C (2009). Life on the edge: life-history of olive baboons at Gashaka-Gumti National Park, Nigeria. American Journal of Primatology 71: 293-304.

Hohmann G, Fruth B (2008). New records on prey capture and meat eating by bonobos at LuiKotale, Salonga National Park, Democratic Republic of Congo. Folia Primatologica 79: 103-110.

Jaeggi AV, Gurven M (2013). Natural cooperators: food sharing in humans and other primates. Evolutionary Anthropology 22: 186-195.

Kingdon J (2015). The Kingdon Field Guide to African Mammals, 2nd ed. Princeton, Princeton University Press.

Kivai SM (2013). Predation on an endemic and endangered Tana River mangabey (Cercocebus galeritus) by a sympatric yellow baboon in Tana River National Primate Reserve, Kenya. African Primates 8 : $59-62$.

Koenig A, Borries C (2009). The lost dream of ecological determinism: time to say goodbye? ... Or a White Queen's proposal? Evolutionary Anthropology 18: 166-174.

Oates JF (2011). Primates of West Africa. A Field Guide and Natural History. Arlington, Conservation International.

Power C, Sommer V, Watts I (2013). The seasonality thermostat: female reproductive synchrony and male behaviour in monkeys, Neanderthals and modern humans. Paleoanthropology 2013: 33-60.

Rhine RJ, Norton GW, Wynn GM, Wynn RD, Rhine HB (1986). Insect and meat eating among infant and adult baboons (Papio cynocephalus) of Mikumi National Park, Tanzania. American Journal of Physical Anthropology 70: 105-118.

Ross C, Warren Y, MacLarnon AM, Higham JP (2011). How different are Gashaka's baboons? Forest and open country populations compared. In Primates of Gashaka. Socioecology and Conservation in Nigeria's Biodiversity Hotspot (Sommer V, Ross C, eds.), pp 333-361. New York, Springer.

Rowell TE (1966). Forest living baboons in Uganda. Journal of Zoology, London 149: 344-364.

Sharman MJ (1982). Feeding, Ranging and Social Organisation of the Guinea Baboon. PhD thesis, University of St Andrews.

Smuts B (1985). Sex and Friendship in Baboons. London, Harvard University Press.

Sommer V, Ross C (2011). Exploring and protecting West Africa's primates. The Gashaka Primate Project in context. In Primates of Gashaka. Socioecology and Conservation in Nigeria's Biodiversity Hotspot (Sommer V, Ross C, eds.), pp 1-37. New York, Springer.

Sommer V, Buba U, Jesus G, Pascual-Garrido A (2012). Till the last drop. Honey gathering in Nigerian chimpanzees. Ecotropica 18: 55-64.

Stanford CB (1998). Chimpanzee and Red Colobus. The Ecology of Predator and Prey. Massachusetts, Harvard University Press.

Stoltz LP, Saayman GS (1970). Ecology and feeding behaviour of baboons in the Northern Transvaal. Annals of the Transvaal Museum 26: 99-143.

Strum SC (1975). Primate predation: interim report on the development of a tradition in a troop of olive baboons. Science 187: 755-757.

Strum SC (1984). Almost Human. A Journey into the World of Baboons. New York, Random House. 
Swedell L (2002). Ranging behavior, group size and behavioral flexibility in Ethiopian hamadryas baboons (Papio hamadryas hamadryas). Folia Primatologica 73: 95-103.

Swedell L, Hailemeskel G, Schreier A (2008). Composition and seasonality of diet in wild hamadryas baboons: preliminary findings from Filoha. Folia Primatologica 79: 476-490.

Warren Y, Higham JP, MacLarnon AM, Ross C (2011). Crop-raiding and commensalism in olive baboons: the costs and benefits of living with humans. In Primates of Gashaka. Socioecology and Conservation in Nigeria's Biodiversity Hotspot (Sommer V, Ross C, eds.), pp 307-332. New York, Springer.

Waser P (1975). Diurnal and nocturnal strategies of the bushbuck Tragelaphus scriptus (Pallas). East African Wildlife Journal 13: 49-63.

Wenninger PS, Shipley LA (2000). Harvesting, rumination, digestion, and passage of fruit and leaf diets by a small ruminant, the blue duiker. Oecologia 123: 466-474.

Zinner D, Buba U, Nash S, Roos C (2011). Pan-African voyagers: the phylogeography of baboons. In Primates of Gashaka. Socioecology and Conservation in Nigeria's Biodiversity Hotspot (Sommer V, Ross C, eds.), pp 267-306. New York, Springer. 